\title{
Evaluation and predictive modeling of shelf life of minced beef stored in high-oxygen modified atmosphere packaging at different temperatures
}

\author{
S. Limbo ${ }^{\text {a,* }}$, L. Torri ${ }^{b}$, N. Sinelli ${ }^{\text {a }}$, L. Franzetti ${ }^{\text {a }}$, E. Casiraghi ${ }^{a}$ \\ a DISTAM, Università degli Studi di Milano, Via Celoria, 2, 20133 Milano, Italy \\ ${ }^{\mathrm{b}}$ University of Gastronomic Sciences, Piazza Vittorio Emanuele 9, 12060 Bra (CN), Italy
}

\section{A R T I C L E I N F O}

\section{Article history:}

Received 21 May 2009

Received in revised form 13 August 2009

Accepted 14 August 2009

\section{Keywords:}

Freshness

e-Nose

Minced beef

High oxygen concentrations

Shelf life

Time-temperature relationship

\begin{abstract}
A B S T R A C T
The aims were: (1) to follow the freshness decay of minced beef stored in high-oxygen modified atmosphere packaging at different temperatures $\left(4.3,8.1\right.$ and $15.5^{\circ} \mathrm{C}$ ) by applying traditional methods (microbiological counts, color evaluation, thiobarbituric acid assay TBA, headspace gas composition) and enose; (2) to model the decay kinetics to obtain information about the maximum shelf life as function of storage conditions. The minced beef, packaged in modified atmosphere was supplied by a manufacturer at the beginning of its commercial life. The study demonstrated the ability of the traditional methods to describe the kinetics of freshness decay. The modeling of the experimental data and the comparison with microbiological or chemical thresholds allowed the setting, for each index, of a stability time above which the meat was no longer acceptable. The quality decay of meat was also evaluated by the headspace fingerprint of the same set of samples by means of a commercial e-nose. A clear discrimination between "fresh" and "old" samples was obtained using PCA and CA, determining at each temperature a specific range of stability time. The mean value of the stability times calculated for each index was 9 days at $4.3{ }^{\circ} \mathrm{C}$ (recommended storage temperature), $3-4$ days at $8.1^{\circ} \mathrm{C}$ (usual temperature in household refrigerators) and 2 days at $15.5^{\circ} \mathrm{C}$ (abuse temperature). Resolution of the stability times allowed calculation of mean $Q_{10}$ values, i.e. the increase in rate for a $10^{\circ} \mathrm{C}$ increase in temperature.

The results show that the $Q_{10}$ values from the traditional methods (3.6-4.0 range) overlapped with those estimated with e-nose and color indexes (3.4 and 3.9, respectively).
\end{abstract}

๑ 2009 Elsevier Ltd. All rights reserved.

\section{Introduction}

Minced meat beef is appreciated because of its convenience. Unfortunately, its shelf life is limited because the large exposed surface area facilitates spoilage. The rate of deteriorative changes depends on meat composition, hygienic practices during cutting, grinding and preparation and, finally, storage conditions. The most important factor in controlling meat spoilage is microbial contamination and growth, which affects safety and color (Brooks et al., 2008). The oxidative effects on myoglobin, causing color deterioration, and lipid oxidation, that can cause rancidity, contribute to secondary defects of off-flavors and off-odors (Duong et al., 2008; Mataragas, Drosinos, Vaidanis, \& Metaxopoulos, 2006).

Modified atmosphere packaging (MAP) is recognized as one of the most effective methods for shelf life extension of fresh meat and is widely used by the industry to reduce spoilage of minced meat (Koutsoumanis, Stamatiou, Drosinos, \& Nychas, 2008). The

\footnotetext{
* Corresponding author. Address: DISTAM, University of Milan, Via Celoria 2, 20133 Milano, Italy. Tel.: +39 02 50316661; fax: +39 0250316672.

E-mail address: sara.limbo@unimi.it (S. Limbo).
}

effectiveness of MAP in shelf life extension of meat is based on the antimicrobial activity of $\mathrm{CO}_{2}$. The presence of $\mathrm{CO}_{2}$ in the headspace of meat packages leads to the inhibition of microbial growth and provokes a shift in the dominant microflora to bacterial groups with less spoilage potential. MAP used for fresh meat usually contains $70-80 \%$ oxygen to encourage myoglobin oxygenation and, therefore, the red color, rendering the meat attractive for the consumer. Oxygen also stimulates the growth of aerobic bacteria and inhibits the growth of anaerobes (McMillin, 2008).

The positive effects induced by MAP could be largely reduced storage at unsuitable temperatures. In fact, when fresh meat in MAP is stored at temperatures higher than suggested, not only will microbial growth and chemical reactions accelerate but the packaging atmosphere will change, contributing to spoilage before the estimated "use by" date. Unfortunately, although most countries have established regulations indicating maximum temperature limits for refrigerated storage, these are often violated (Koutsoumanis, Stamatiou, Skandamis, \& Nychas, 2006). In fact, temperature control is totally lacking from the store to preparation and final consumption. For example, in South European countries $30 \%$ of refrigerated foods were kept above $10^{\circ} \mathrm{C}$ in retail cabinets and household refrigerators and even in North Europe 5\% were 
above $1{ }^{\circ} \mathrm{C}$ in retail and $21 \%$ above $10{ }^{\circ} \mathrm{C}$ in households (Kennedy et al., 2005).

The definition of meat freshness is important for consumers, the meat industry and retailers. Several scientific works have been carried out considering the spoilage of minced meat, stored at different temperatures, and the methods to assess meat freshness; in particular, as reported by Byun et al. (2003), more than 40 methods have been proposed for the detection and measurements of bacterial spoilage in meats. Also predictive microbiology has been successfully used to predict the effect of various time-temperature storage conditions on the shelf life of minced meat (McMeekin \& Ross, 1996; Shimoni \& Labuza, 2000). Few works have evaluated meat freshness through measurement of changes, such as protein breakdown and fat spoilage (Byun et al., 2003) or the description of sensory attributes. Since microbial analysis is expensive and time consuming, in the last years, non invasive and less time consuming approaches have been assessed (Boothe \& Arnold, 2002; Sierra et al., 2008) suggesting the effective potential of these techniques for monitoring freshness decay.

In this work, the modeling of minced beef shelf life decay was studied on the basis of microbiological indices, rancidity development (thiobarbituric acid assay TBA), headspace gas composition and volatile profile (e-nose). The main goal was to estimate a stability time and its dependence on storage temperature in order to obtain useful information on commercialization and home storage of a delicate and perishable fresh food.

\section{Materials and methods}

\subsection{Thermal exposition of minced meat in the domestic refrigerator}

Small time-temperature (TT) recording devices (TB Econorma SAS), water proof, $\pm 5^{\circ} \mathrm{C}$ temperature tolerance, diameter $=1 \mathrm{~cm}$, thickness $=4 \mathrm{~mm}$, were employed for the evaluation of the exposure conditions during home storage of packaged minced beef. The time-temperature devices were inserted into trays containing minced beef and then distributed to 19 people who placed them in domestic refrigerators. After 5-7 days the TT devices were recovered and read.

\subsection{Minced beef storage}

Minced beef ( $93 \%$ lean) was purchased immediately after grinding and packaging in a commercial meat plant that serves some large retailers in Italy. The product was minced with an industrial mincer equipped with a $4 \mathrm{~mm}$ plate. The preformed trays containing $600 \mathrm{~g}$ of minced beef were evacuated and flushed with the modified atmosphere composed by $30 \% \mathrm{CO}_{2}$ and $70 \% \mathrm{O}_{2}$ before their sealing using an automatic fill-seal packaging system equipped with a gas mixer. The package consisted of a barrier polystyrene foam tray with a perforated bottom and a clear top film, both oxygen impermeable with a maximum oxygen transmission rate of $0.1 \mathrm{~cm}^{3} 24 \mathrm{~h}^{-1} \mathrm{~m}^{-2}$ and $20 \mathrm{~cm}^{3} 24 \mathrm{~h}^{-1} \mathrm{~m}^{-2}$, respectively, at $23{ }^{\circ} \mathrm{C}$ and $0 \%$ relative humidity. Inside the trays, no soaker pads were added. Sixty trays were transferred to the laboratory under refrigerated conditions $\left(3^{\circ} \mathrm{C} \pm 1\right)$ within $1 \mathrm{~h}$ and upon arrival they were stored at three different controlled temperatures $(4,8$ and $\left.15^{\circ} \mathrm{C}\right)$.

The average storage temperatures were measured by a timetemperature recording devices (TB Econorma SAS) and were respectively $4.3,8.1$ and $15.5^{\circ} \mathrm{C}$, with a standard deviation of less than 0.2 . Samples stored at $4.3^{\circ} \mathrm{C}$ were analyzed after $1.0,1.9$, $2.8,6.2,7.0,8.0,9.0,10.0$, and 11.0 days; those stored at $8.1^{\circ} \mathrm{C}$ after $0.8,1.8,2.8,3.8,6.2,7.2$, and 8.2 days and the ones at $15.5^{\circ} \mathrm{C}$ after $0.9,1.1,1.9,2.9,3.9$ days of storage. At these two last temperatures fewer points were recorded because of the greater rate of decay of the meat. All the analyses were performed in triplicate.

\subsection{Microbiological analyses}

At established storage times, ten grams of minced beef were aseptically removed from each package, transferred into sterile stomacher bags, homogenized with $90 \mathrm{~mL}$ of $0.85 \%$ sterile tryptone salt solution and blended in stomacher (Colworth 400) for 2 min. Decimal progressive dilutions were prepared. Mesophylic aerobic count or Total Bacterial Count (TBC) was evaluated on Plate Count Agar (Merck, VWR, Germany) (ISO, 4833:2003), by pour plates aerobic incubation at $30{ }^{\circ} \mathrm{C}$ for $48 \mathrm{~h}$. Lactic Acid Bacteria were evaluated onto a Man Rogosa Sharpe (MRS) medium (Difco, Italy) (De Man, Rogosa, \& Sharpe, 1960), by pour plates, incubation in anaerobic conditions (gas pack) at $30^{\circ} \mathrm{C}$ for $48 \mathrm{~h}$. Finally, Gram negative bacteria were evaluated by spread technique on Plate Count Monesin- $\mathrm{KCl}$ Agar Mug (PMK Mug, made up of $23.5 \mathrm{~g}$ plate count agar; $35 \mathrm{mg}$ monensin; $7.5 \mathrm{~g} \mathrm{KCl} ; 75 \mathrm{mg} 4$ methylumbelliferyl-D-glucuronide (Mug)) aerobic incubation at $30^{\circ} \mathrm{C}$ for $48 \mathrm{~h}$. Each microbiological determination was performed in triplicate and the results were expressed as the average colony forming units per gram (CFU/g).

\subsection{Mathematical modeling of bacterial growth}

Bacterial growth curves were generated by fitting the data with the modified Gompertz equation, as reported by Zwietering, De Koos, Hasenack, De Witt, and Van't Riet (1991) (Eq. (1)) and the response variables (lag time, maximal growth rate and maximal cell concentration) were estimated

$$
\begin{aligned}
\log (\mathrm{CFU})= & K+A \\
& * \exp \left\{-\exp \left\{\left[\left(\mu_{\max } * 2.7182\right) * \frac{\mathrm{LPD}-t}{A}\right]+1\right\}\right\}
\end{aligned}
$$

where $K$ is the initial level of bacterial count $(\log \mathrm{CFU} / \mathrm{g}) ; A$ is the increase in $\log \mathrm{CFU} / \mathrm{g}$ between time 0 and the maximum population density achieved at the stationary phase; $\mu_{\max }$ is the maximal growth rate $(\Delta \log (\mathrm{CFU} / \mathrm{g}) /$ day $)$; LPD is the lag phase duration (days) and $t$ is the storage time (days). The goodness of the fit was assessed by the $R^{2}$ value.

\subsection{Color evaluation}

Instrumental color in CIELAB space of minced meat was measured by a hand-held tri-stimulus colorimeter (Minolta Chroma Meter CR-210, Minolta, Osaka, Japan) with a $8 \mathrm{~mm}$ viewing port, $2^{\circ}$ standard observer and a $\mathrm{C}$ illuminant source. Before each measurement, the apparatus was calibrated on the Hunterlab color space system using a white ceramic tile (Minolta calibration plate, $Y=92.6, x=0.3136, y=0.3196)$. Color was described as coordinates: lightness $\left(L^{*}: 100=\right.$ white, $0=$ black $)$, redness $\left(a^{*} \pm\right.$ redgreen) and yellowness $\left(b^{*} \pm\right.$ yellow-blue). In order to monitor meat browning over storage, hue angle $\left(H=\arctan b^{*} / a^{*}\right.$; higher values are more brown) was calculated.

\subsection{TBA determination}

The thiobarbituric acid (TBA) assay was performed following the method proposed by Raharjo, Sofos, and Schmidt (1993). Ten gram of minced meat were homogenized with $40 \mathrm{~mL}$ of $5 \%(\mathrm{w} / \mathrm{v})$ aqueous trichloroacetic acid (TCA) at room temperature for $1 \mathrm{~min}$. The homogenate was centrifuged at $10,000 \mathrm{~g}$ for $5 \mathrm{~min}$ and the supernatant was filtered through a Whatman micro fiber glass 
filter grade C (Whatman, GF/C Intern Ltd Maidstone, England) into a volumetric flask. Filtrate volume was adjusted to $50 \mathrm{~mL}$ using $5 \%$ $(\mathrm{w} / \mathrm{v})$ TCA. A volume of $5 \mathrm{~mL}$ was reacted with $5 \mathrm{~mL}$ of $80 \mathrm{mM}$ TBA in a test tube with a screw cap, while heating in a water bath at $94 \pm 1{ }^{\circ} \mathrm{C}$ for $5 \mathrm{~min}$. The $\mathrm{pH}$ of was adjusted to 7 with $5 \mathrm{~N} \mathrm{NaOH}$ and $0.2 \mathrm{~mL}$ of $3 \%(\mathrm{w} / \mathrm{v})$ phosphate buffer of $\mathrm{pH} 7.2$ prior to pumping to a solid phase extraction Sep-Pak ${ }^{\mathrm{TM}} \mathrm{C}_{18}$ cartridge (Waters, Italy). After cartridge conditioning with methanol and water, $10 \mathrm{~mL}$ of the sample were loaded and the eluted solution from the cartridge was discarded. Unreacted TBA solution and other components were removed by eluting the loaded sample with $10 \mathrm{~mL}$ of distilled water. The red malonaldehyde-TBA complex was recovered and separated from other thiobarbituric acid reactive substances (TBARS) by eluting the cartridge with $10 \mathrm{~mL}$ of absolute methanol. The absorbance of the methanol eluent containing the malonaldehyde-TBA complex was measured at $525 \mathrm{~nm}$ using a double beam UV/Vis spectrophotometer (Perkin Elmer Lambda 25, Italy). The calibration curve was obtained from serial diluted solutions of a $10^{-3} \mathrm{M}$ of TEP (1,1,3,3-tetra-etoxypropane), following the same procedure. The results were expressed as mg malonaldehyde per $\mathrm{kg}$ meat.

\subsection{Head space gas composition}

A small quantity $(40 \mu \mathrm{L})$ of the atmosphere inside the trays stored at different temperatures was sampled at regular intervals using a gas tight syringe through a septum glued onto the package surface, and analyzed using a gas chromatograph (Hewlett-Packard HP 5890 series II) equipped with a thermoconductivity detector and a steel column ( $2 \mathrm{~m} \times 6 \mathrm{~mm}$, CTR I Alltech, Milano).

\subsection{Electronic nose}

A commercial portable electronic nose (PEN 2 model) from Win Muster Airsense (WMA) Analytic Inc. (Schwerim, Germany) was used. It consists of a sampling apparatus, a detector unit containing the array of sensors and patter recognition software (Win Muster v.16) for data recording and elaboration. The sensor array system is composed of 10 metal oxide semiconductors (MOS) of different chemical composition and thickness to provide selectivity towards volatile compound classes as indicated by the instrument supplier: W1C (aromatic), W5S (broadrange), W3C (aromatic), W6S (hydrogen), W5C (aromatic-aliphatics), W1S (broad-methane), W1W (sulphur-organic), W2S (broad-alcohol), W2W (sulphur-chlorinate) and W3S (methane-aliphatics). The sensor response is expressed as resistivity (Ohm). The MOS sensors rely on changes in conductivity induced by the adsorption of molecules in the gas phase and on subsequent surface reactions. They consist of a ceramic substrate coated by a metal oxide semiconducting film, and heated by a wire resistor. Due to the high operating temperatures $\left(200-500{ }^{\circ} \mathrm{C}\right)$ the organic volatiles transferred to the surface of the sensors are totally combusted to carbon dioxide and water, leading to a change in the resistance. The use of the high temperature avoids water interference and aids rapid response and recovery times (Khol, 1991). The detection limit of hot sensors is in the range $1 \mathrm{ppm}$.

At each storage time and for each temperature, $8 \mathrm{~g}$ of minced meat were placed into $45 \mathrm{~mL}$ glass vials, sealed with a PTFE/silicone septum and a screw cap. The vials were stored at $-25^{\circ} \mathrm{C}$ until analysis. Then, the vials were equilibrated at $23 \pm 1^{\circ} \mathrm{C}$ for $90 \mathrm{~min}$ and analyzed at the same temperature. The measurement device sucked the gaseous compounds from the headspace of the sample through the sensor array at $300 \mathrm{~mL} / \mathrm{min}$ for $180 \mathrm{~s}$. After sample analysis the system was purged for $400 \mathrm{~s}$ at a flow rate of $600 \mathrm{~mL} / \mathrm{min}$ with filtered air prior injection of the next sample to allow the instrument base line to be re-established. For each tem- perature and at each storage time, five different samples were analyzed and the average was used for statistical analyses.

\subsection{Statistical analyses}

Principal component analysis (PCA) was used to treat the e-nose data (XLStat software, version 2006.3). Instrumental responses were also analyzed by cluster analysis (CA), applying an Euclidean distance and a Ward method of linkage (XLStat software, version 2006.3)

\section{Results and discussion}

\subsection{Thermal exposition of minced meat in the domestic refrigerator}

The storage temperatures were selected considering two of the most important distribution steps of packaged fresh meat: the sale point and subsequent household storage. In the first case, a temperature of about $4{ }^{\circ} \mathrm{C}$ was chosen because it often represents the recommended condition for the storage of meat during retail display, while in the second case, the 19 thermal histories obtained during storage in domestic refrigerators were used.

The data obtained from the 19 thermal histories during the household storages were statistically analyzed and plotted in an exposure probability chart (Fig. 1). Fig. 1 shows the great variability of the thermal histories due to the casual location of the meat packages inside the refrigerators. From the raw data, the cumulative frequency distributions were also computed and plotted on the same time-temperature exposure probability chart. It was considered that a probability of $50 \%$ can be referred to as average exposure; a probability of $75 \%$ to the real exposure and the probability of $90 \%$ to the most severe hypothesis (Jul, 1984).

The average temperature during home storage of the meat was $6.6^{\circ} \mathrm{C}$ but 3 times out 4 (corresponding to the real exposure) the temperature of the meat was $8.4^{\circ} \mathrm{C}$. For this reason, the effects of storage at about $8{ }^{\circ} \mathrm{C}$ on meat freshness were investigated.

During large-scale distribution and handling of meat there are numerous opportunities for meat to be temperature abused. These include loading and unloading of meat and subsequent transportation by trucks (refrigerated or unrefrigerated) to retail outlets where the meat has to be unloaded again and stacked for storage (Zhu, Mendonca, \& Ahn, 2004). Substantial data exists concerning the shelf life of minced beef held at optimal temperatures (0$4{ }^{\circ} \mathrm{C}$ ) (Leak \& Rönnow, 1999). However, little data on quality changes in minced meat by temperature abuse is available; therefore this study was also designed to evaluate shelf life at about $16{ }^{\circ} \mathrm{C}$.

\subsection{Microbiological development during storage}

During storage at the three selected temperatures (4.3, 8.1 and $\left.15.5^{\circ} \mathrm{C}\right)$, the changes in Total Bacterial Count (TBC), lactic acid (LAB) and gram negative bacteria were monitored. Initial counts for total bacteria were approximately $4 \log 10 \mathrm{CFU} / \mathrm{g}$. At each temperature, the growth of microbial populations was described with the Gompertz modified function (Zwietering, De Koos, Hasenack, De Witt, \& Van't Riet, 1991). In all cases, good agreement between experimental data and predicted values was obtained. Some growth parameters lag phase duration (LPD) and maximal growth rate $\left(\mu_{\max }\right)$, obtained by the model, with their respective standard error and the coefficient of determination $\left(R^{2}\right)$ are shown in Table 1.

Generally, to define shelf life, it is necessary to establish both quality indexes and their critical limits, i.e. the levels above or below which the product is no longer acceptable. In the case of meat, there are a number of opinions concerning the amount and the 


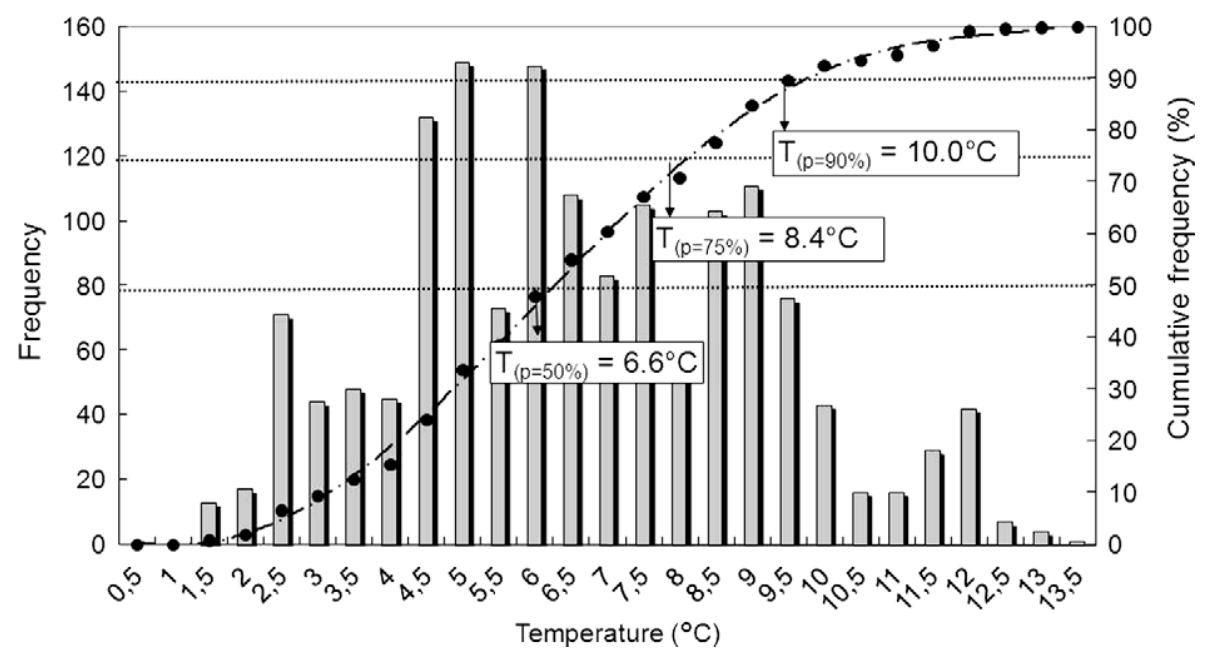

Fig. 1. Temperature frequency inside domestic refrigerator.

Table 1

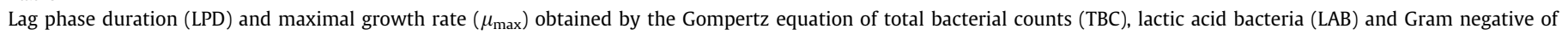
minced beef stored at $4.3,8.1$ and $15.5^{\circ} \mathrm{C}$.

\begin{tabular}{|c|c|c|c|c|}
\hline & $T\left({ }^{\circ} \mathrm{C}\right)$ & LPD (days) & $\mu_{\max }(\Delta \log (\mathrm{CFU} / \mathrm{g}) /$ day $)$ & $R^{2}$ \\
\hline TBC & $\begin{array}{l}4.3 \\
8.1 \\
15.5\end{array}$ & $\begin{array}{l}6.62(0.13) \\
2.98(0.33) \\
1.19(0.05)\end{array}$ & $\begin{array}{l}0.31(0.03) \\
0.40(0.02) \\
0.84(0.08)\end{array}$ & $\begin{array}{l}0.98 \\
0.98 \\
0.99\end{array}$ \\
\hline LAB & $\begin{array}{l}4.3 \\
8.1 \\
15.5\end{array}$ & $\begin{array}{l}6.34(0.17) \\
1.11(0.09) \\
0.15(0.03)\end{array}$ & $\begin{array}{l}0.26(0.02) \\
0.50(0.03) \\
1.31(0.11)\end{array}$ & $\begin{array}{l}0.99 \\
0.99 \\
0.99\end{array}$ \\
\hline Gram negative & $\begin{array}{l}4.3 \\
8.1 \\
15.5\end{array}$ & $\begin{array}{l}6.03(0.98) \\
3.12(0.16) \\
1.24(0.07)\end{array}$ & $\begin{array}{l}0.16(0.01) \\
0.28(0.04) \\
0.60(0.10)\end{array}$ & $\begin{array}{l}0.98 \\
0.98 \\
0.99\end{array}$ \\
\hline
\end{tabular}

type of bacteria that must be present before meat is considered spoiled (Brooks et al., 2008).

Several scientists have concluded that bacterial counts of $10^{7}$ and $10^{8} \mathrm{CFU} / \mathrm{cm}^{2}$ can cause noticeable off-odors and slime, (Jay, 1996; Lambert, Smith, \& Dodds, 1991; Nassos, King, \& Stafford, 1983). As reported by Brooks et al. (2008) some authors stated that microbial populations on raw beef must reach approximately $10^{8}$ $\mathrm{CFU} / \mathrm{g}$ to show tackiness when touched, whereas others have claimed that proteolytic changes do not occur until bacterial populations are greater than $3.2 \times 10^{9} \mathrm{CFU} / \mathrm{cm}^{2}$ are reached.

Within certain environmental conditions, only one species of the microflora is often responsible for spoilage (specific spoilage organism-SSO). The spoilage becomes evident when a certain spoilage level is reached by the SSO and/or its microbial metabolic product.

From Table 1 it is evident that LABs had higher rates of growth than Gram negative bacteria at the three temperatures. The use of $\mathrm{CO}_{2}$ in MAP can improve storage by allowing the growth of LAB such as Lactobacillus spp. and Leuconostoc spp. and thus outcompeting Enterobacteriaceae, Pseudomonas spp., and Brochothrix thermosphacta. Moreover, the use of high $\mathrm{CO}_{2}$ concentration and chill storage, can more readily inhibit the growth of food pathogens than vacuum packaging (Ercolini, Russo, Torrieri, Masi, \& Villani, 2006).

In order to determine the thermal sensitivity of contaminant microorganisms during storage, the temperature effects on lag phase duration and maximum specific rate of LAB and gram negative bacteria were estimated by means of Arrhenius functions (Giannuzzi, Pinotti, \& Zaritzky, 1998; Koutsoumanis \& Nichas, 2000; Mataragas et al., 2006). In particular, the adaptation rate of microorganisms, defined as the reciprocal of lag phase (1/LDP) was fitted with the following equation:

$1 / \mathrm{LDP}=Z \exp \left(-E_{\mathrm{LDP}} / R T\right)$

where $Z$ is the pre-exponential factor $\left(\right.$ days $\left.^{-1}\right), T$ the absolute temperature, $E_{\mathrm{LDP}}$ is the activation energy $(\mathrm{kJ} / \mathrm{mol})$ and $R$ is the gas constant $\left(8.31 \mathrm{~J} / \mathrm{K}^{*} \mathrm{~mol}\right)$.

The effect of temperature on the specific growth rate was described by the following equation:

$\mu=A^{\prime} \exp \left(-E_{\mu} / R T\right)$

where $\mu$ is the specific growth rate $\left[\log (\mathrm{CFU} / \mathrm{g})\right.$ days $\left.^{-1}\right]$ and $\mathrm{A}^{\prime}$ the pre-exponential factor $\left[\log (\mathrm{CFU} / \mathrm{g})\right.$ days $\left.^{-1}\right]$. Plotting $\operatorname{lnLDP}$ or $\ln \mu_{\max }$ versus $1 / T$, allows calculation of $E_{\mathrm{LDP}}$ and $E \mu_{\max }$ for each type of bacteria. The data are presented in Table 2.

The high $R^{2}$ values show an Arrhenius dependence on temperature both for LAB and Gram negative microorganisms. Concerning the effect of temperature on lag phase duration and specific growth rate, the higher activation energy values of LAB indicated that their growth was affected more by temperature shifts than the growth of Gram negative microorganisms.

Table 2

Application of arrhenius model to evaluate the effect of temperature on lag phase duration and specific growth rate for LAB and gram negative microorganisms.

\begin{tabular}{lllll}
\hline Microorganism & $E_{\text {LDP }}(\mathrm{kJ} / \mathrm{mol})$ & $R^{2}$ & $E \mu_{\max }(\mathrm{kJ} / \mathrm{mol})$ & $R^{2}$ \\
\hline LAB & 217.5 & 0.982 & 94.16 & 0.997 \\
Gram negative & 92.80 & 0.994 & 77.60 & 0.982 \\
\hline
\end{tabular}


The formation of $\mathrm{CO}_{2}$ in the package was followed during storage in order to identify the value of LAB and Gram negative that can be considered as the limit. In fact, the gaseous environment within a modified atmosphere pack is not static and respiration products, microbial metabolism (especially due aerobic microbiota) and gas permeability continually modify the composition within the package (O'Grady, Monahan, Burke \& Allen, 2000).

This phenomenon was investigated by gas chromatography and Fig. 2, shows the formation of $\mathrm{CO}_{2}$ during storage at the three temperatures.

A simple transition kinetic was applied to the data to identify (after second derivative transformation) a threshold time, namely the time corresponding to the maximum value of the second derivative of the function. In this way, a maximum acceptability time for each storage temperature was computed from the kinetic model: $9.27 \pm 0.72$ days for storage at $4.3^{\circ} \mathrm{C} ; 5.71 \pm 0.63$ days at $8.1^{\circ} \mathrm{C}$ and $2.06 \pm 0.13$ days at $15.5^{\circ} \mathrm{C}$.

LAB and Gram negative counts corresponding to these threshold times were estimated considering their modeled growth curves (data not shown). The obtained values for LAB and Gram negative were around $10^{7} \mathrm{ufc} / \mathrm{g}$, in accordance with Koutsoumanis et al. (2008) who indicated $10^{7}$ as the average spoilage level for dominant bacteria groups in fresh meat.

\subsection{Color evaluation}

In the definition of shelf life, spoilage cannot be considered as the result of bacterial numbers per se, but spoilage also depends on biochemical changes which occur during microbial growth (Nassos et al., 1983). The microbial development was compared with other indexes (color, TBA, and volatile aroma compounds) of freshness decay of packaged minced beef.

The color of fresh meat is one of the most important factors that influence customer selection because consumers use discoloration as an indicator of freshness and wholesomeness (Mancini \& Hunt, 2005). Lightness $\left(L^{*}\right)$, redness $\left(a^{*}\right)$ and yellowness $\left(b^{*}\right)$ were measured and used to calculate the hue index (Fig. 3). The increase in of hue index depended on the storage temperature and time as reported by others authors (Akarpat, Turhan, \& Ustun, 2008; Georgantelis, Blekas, Katikou, Ambrosiadis, \& Fletouris, 2007). This increase was explained by the gradual oxidation of myoglobin and accumulation of metmyoglobin with time (Mancini \& Hunt, 2005; Ruiz de Huidobro, Miguel, Onega, \& Blázquez, 2003).

As for headspace composition, the trend of the browning $(\Delta H u e)$ was interpolated with a pseudo-sigmoidal function and parameterized by inspection of the second derivative, allowing the computation of a threshold time for each storage test (9.37,

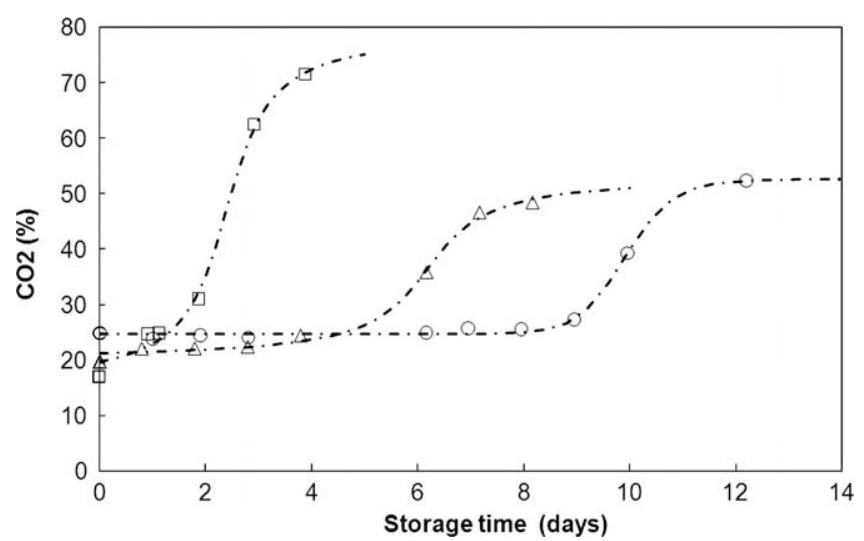

Fig. 2. Formation of $\mathrm{CO}_{2}$ in the headspace of MAP packaged minced beef stored at different temperatures $\left(04.3^{\circ} \mathrm{C} ; \triangle 8.1^{\circ} \mathrm{C} ; \square 15.5^{\circ} \mathrm{C}\right)$.

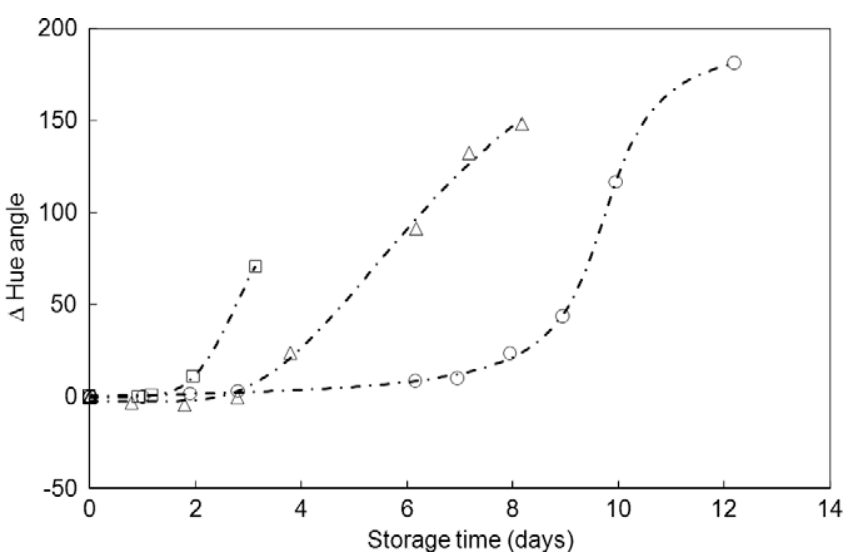

Fig. 3. Hue angle trend during storage of minced meat at different temperatures (o $4.3^{\circ} \mathrm{C} ; \triangle 8.1^{\circ} \mathrm{C} ; \square 15.5^{\circ} \mathrm{C}$ ).

3.13 and 2.12 days, respectively, with increasing storage temperature).

\subsection{TBA determination}

The development of oxidative off-flavors (rancidity) has long been recognized as a serious problem during the storage of meat products. TBA along with hexanal content are considered lipid oxidation markers in meat and meat products (Shahidi, Yun, Rubin, \& Wood, 1987). High-oxygen atmosphere packaging is associated with increased TBA numbers during storage (O'Grady et al., 2000) and any disruption of muscle membranes integrity, as in minced beef, facilitates the interactions of prooxidants with unsaturated fatty acids resulting in the generation of free radicals and the propagation of oxidative reactions (Gray, Gomaa, \& Buckley, 1996).

Although oxidative rancidity is not the dominant event during storage at refrigeration temperatures, it can contribute to unpleasant odors and flavors reducing the sensorial and nutritional value of the meat. The amount of 2-thiobarbituric acid complex (TBA values) evaluated in stored minced beef, was expressed as mg malonaldehyde per $\mathrm{kg}$ meat and its formation during storage followed zero order kinetics (Fig. 4). TBA values obtained at $4.3^{\circ} \mathrm{C}$ were in accordance with those reported by O'Grady et al. (2000).

For secondary oxidation products, such as, TBA, no legal threshold exists, but a limit of $1 \mathrm{mg}$ malonaldehyde/kg meat has been suggested for sensory perceived rancidity (Jayasingh, Cornforth,

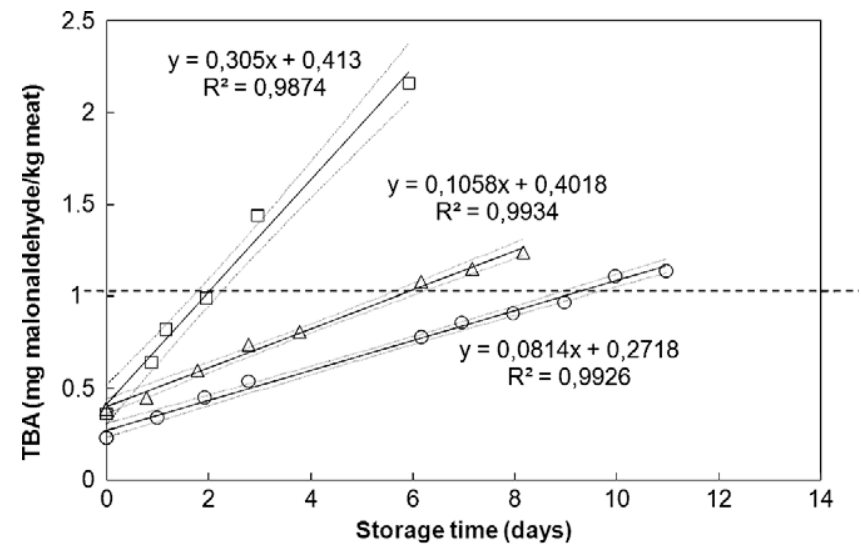

Fig. 4. Trend of TBA index (expressed as malonaldeyde) in MAP minced meat stored at different temperatures (o $4.3^{\circ} \mathrm{C} ; \triangle 8.1^{\circ} \mathrm{C} ; \square 15.5^{\circ} \mathrm{C}$ ). 
Brennand, Carpenter, \& Whittier, 2002; Tarladgis, Watts, Younathan, \& Dugan, 1960). Thus a time threshold for each storage temperature was computed, considering a TBA value of 1 (mg malonaldehyde $/ \mathrm{kg}$ meat) yielding the following values: $8.95 \pm 0.47$ days at $4.3^{\circ} \mathrm{C} ; \quad 5.65 \pm 0.25$ days at $8.1^{\circ} \mathrm{C}$ and $1.92 \pm 0.25$ days at $15.5^{\circ} \mathrm{C}$.

\subsection{Electronic nose}

To study the development of volatile aroma compounds, the electronic nose was applied. Several studies have investigated the volatile changes in a variety of different meats, such as pork (Hansen, Petersen, \& Byrne, 2005), poultry (Rajamäki et al., 2006), and a meat product used as pizza topping (Vestergaard, Martens, \& Turkki, 2007). Also fresh beef (Winquist, Hörnsten, Sundgren, \& Lundström, 1993), beef stored under vacuum (Blixt \& Borch, 1999) and modified atmosphere (Friedrich et al., 2008) have been studied. The fairly wide use of this technique is due to the fact that e-nose is a rapid, convenient and solvent less method (Gardner \& Bartlett, 1994).

In all the storage conditions, the e-nose multi-sensor system was able to determine the kinetics of quality decay. Some sensors show increased response as function of storage time, according to

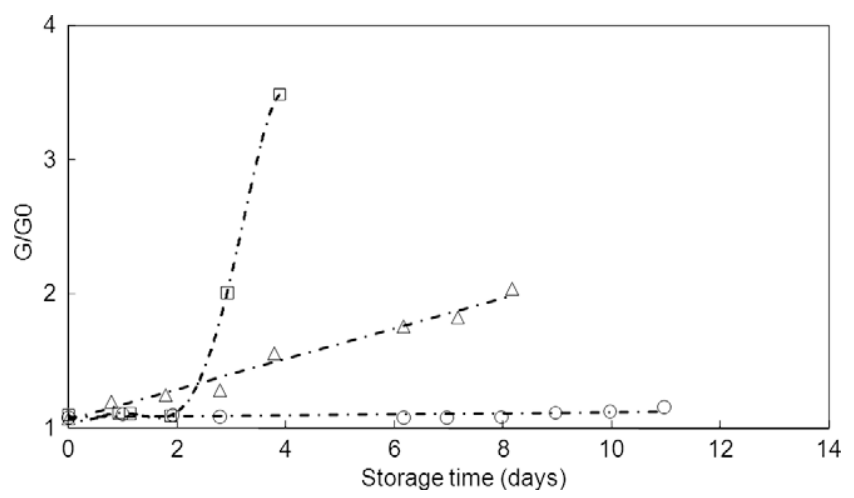

Fig. 5. Trend of the W6S sensor signal during storage at different temperatures (o $4.3^{\circ} \mathrm{C} ; \triangle 8.1^{\circ} \mathrm{C} ; \square 15.5^{\circ} \mathrm{C}$ ).
Winquist et al. (1993) and Olsen et al. (2005), while others were not so sensitive.

At $4.3^{\circ} \mathrm{C}$, the W5S sensor provided the highest response during the whole storage period and contributed significantly to the discrimination of the samples, as did the W6S, W1S, W2S and W1W sensors. On the other hand, the lowest responses were provided by the W1C, W3C and W5C sensors, which, nevertheless, showed good ability in differentiating sample odor. Similar trends were also obtained at 8.1 and $15.5^{\circ} \mathrm{C}$. Focusing on the trends of singular sensors, as an example, Fig. 5 shows the response of the W6S sensor during storage at the three different temperatures. The signal intensity was clearly influenced by the storage temperature, in good agreement with Boothe and Arnold (2002). The W6S response increases linearly at 4.3 and $8.1^{\circ} \mathrm{C}$, while at $15.5^{\circ} \mathrm{C}$ the sensor response shows a very sharp increase between 2 and 4 days.

According to the usual protocol for multi-sensor devices data analysis (Kent et al., 2004), the sensor responses were elaborated by Principal Component Analysis (PCA). PCA was performed on a covariance matrix. The two first principal components, PC1 and PC2, accounted $87 \%$ of the total variance, $71 \%$ and $17 \%$, respectively. The bi-plot (a scatter plot for scores and loadings) illustrated the mutual relationships between samples and sensors (Fig. 6).

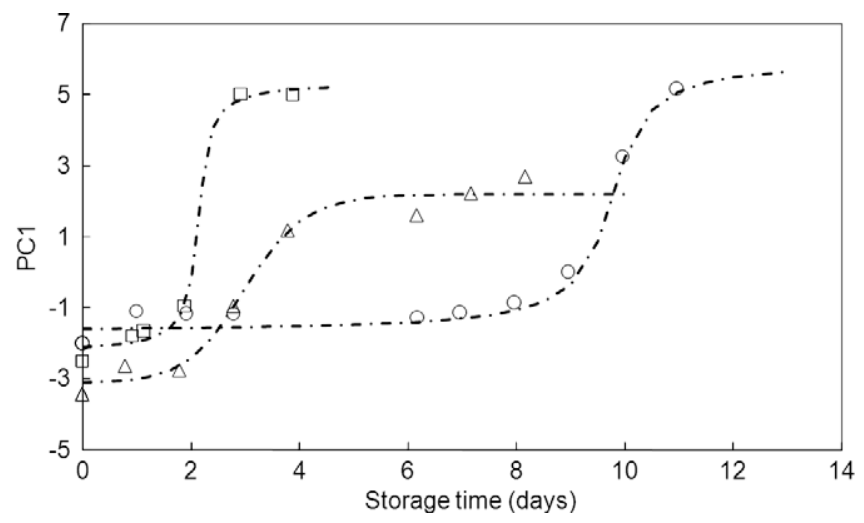

Fig. 7. PC1 score trend during storage at $4.3,8.1$ and $15.5^{\circ} \mathrm{C}\left(\mathrm{o} 4.3{ }^{\circ} \mathrm{C} ; \triangle 8.1^{\circ} \mathrm{C}\right.$; $\square$ $\left.15.5^{\circ} \mathrm{C}\right)$.

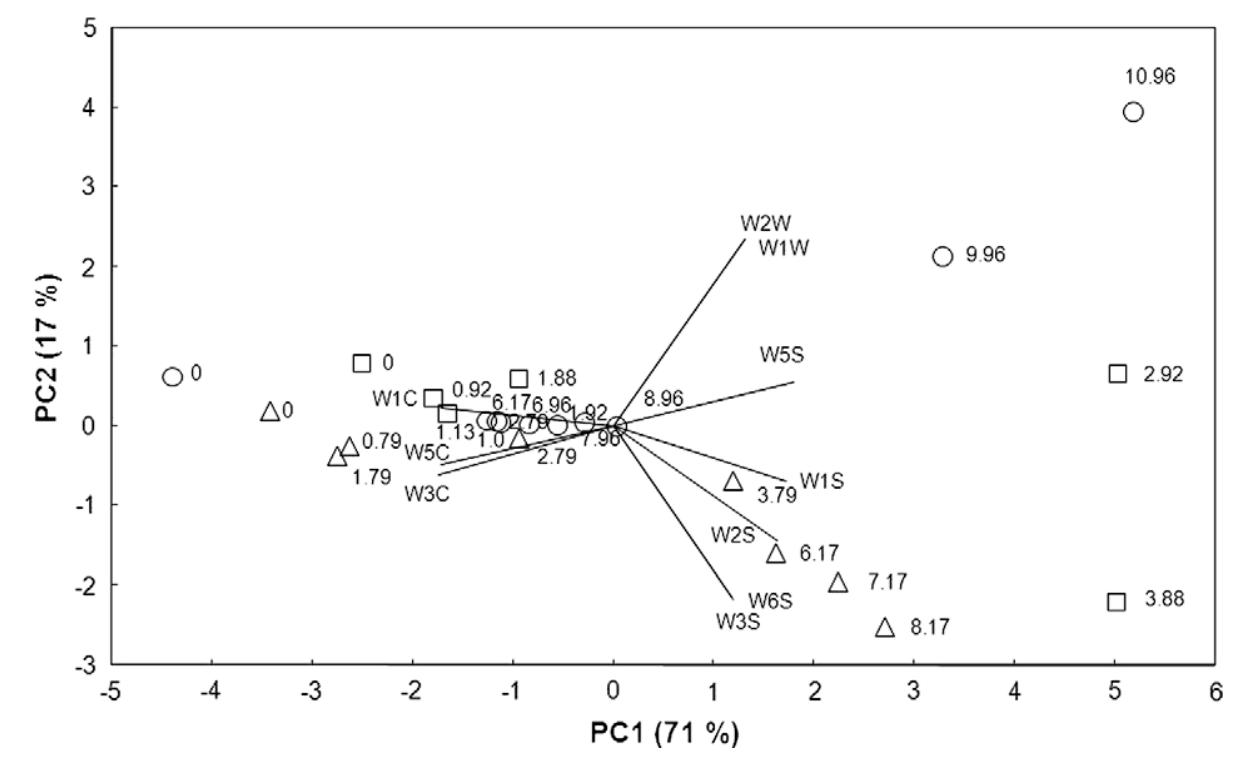

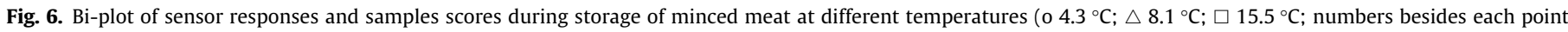
indicate the storage time in days). 
Table 3

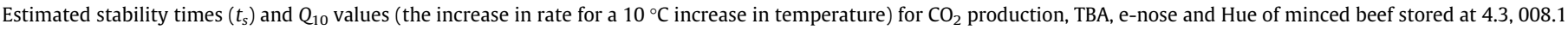
and $15.5^{\circ} \mathrm{C}$.

\begin{tabular}{|c|c|c|c|c|c|}
\hline \multirow[t]{2}{*}{ Analysis } & \multirow[t]{2}{*}{ Definition of $t_{s}$} & \multicolumn{3}{|l|}{ Estimated $t_{s}$} & \multirow[t]{2}{*}{$Q_{10}$} \\
\hline & & $4.3^{\circ} \mathrm{C}$ & $8.1^{\circ} \mathrm{C}$ & $15.5^{\circ} \mathrm{C}$ & \\
\hline $\mathrm{CO}_{2}$ production & $\mathrm{d}^{2}\left(\mathrm{CO}_{2}\right) / \mathrm{dt}^{2}$ & $9.27(0.72)$ & $5.71(0.63)$ & $2.06(0.13)$ & 3.97 \\
\hline TBA & Limit $1 \mathrm{mg} \mathrm{MA} / \mathrm{kg}$ meat & $8.95(0.47)$ & $5.65(0.25)$ & $1.92(0.25)$ & 3.60 \\
\hline e-Nose & $\mathrm{d}^{2}(\mathrm{PC} 1) / \mathrm{dt}^{2}$ & $8.70(0.72)$ & $3.30(1.35)$ & $1.90(0.91)$ & 3.39 \\
\hline Hue & $\mathrm{d}^{2}$ (Hue) $/ \mathrm{dt}^{2}$ & $9.37(0.54)$ & $3.93(1.01)$ & $2.12(0.73)$ & 3.86 \\
\hline Mean value & & $9.07(0.31)$ & $4.65(1.22)$ & $2.01(0.10)$ & $3.71(0.26)$ \\
\hline
\end{tabular}

Sample separation according to the storage conditions is shown on the bi-plot. In fact, samples were distributed along PC1 and PC2 according to storage time and storage temperature, respectively. The results confirm the effectiveness of the e-nose approach, which gives a fingerprint of minced meat freshness. Moreover the sensors sensitive to aromatic and aromatic-aliphatic compounds (W1C, W3C and $\mathrm{W} 5 \mathrm{C}$ ) describe samples during the first days of storage. On the contrary, the sensors more sensitive towards alcohols and sulphur organic compounds (W1W, W2W, W1S, W2S) mainly describe the old samples. These compounds, in fact, contributed to the spoilage odor developed during storage. The responses of enose sensors at each temperature were also elaborated by cluster analysis (CA) (Ward and the square Euclidian distance methods) in order to investigate the similarities among the samples. CA identified two main groups of samples as follow: "fresh meat" corresponding to $0-9$ days at $4.3^{\circ} \mathrm{C}, 0-3$ days at $8.1^{\circ} \mathrm{C}$ and $0-2$ days at $15.5^{\circ} \mathrm{C}$; "old meat" for the other storage conditions. Samples characterized by a weak odor have been classified in the first group, likewise, strongly smelling meat samples have been assembled in the second group.

CA results give the same sample distribution of PCA; in fact in Fig. 6 "fresh meat" is located on the left side of the bi-plot in correspondence of the $\mathrm{W} 1 \mathrm{C}, \mathrm{W} 3 \mathrm{C}$, and $\mathrm{W} 5 \mathrm{C}$ sensors, whereas "old meat" is located in the opposite area in the plot, influenced by the response of the other e-nose sensors.

In order to define a pseudo stability time for freshness maintenance the trend of PC1 samples scores vs. storage time was considered (Benedetti, Sinelli, Buratti, \& Riva, 2005; Sinelli, Barzaghi, Giardina, \& Cattaneo, 2005). Fig. 7 shows these data modeled; i.e. the empirical transition function interpolating PC1 scores at each temperature. The minimum of the second derivative of these functions allowed measurement of the maximum acceptability time for freshness decay revealed by e-nose, that can be considered the "stability" time. Stability time was 8.7 days at $4.3^{\circ} \mathrm{C}, 3.3$ days at $8.1^{\circ} \mathrm{C}$ and 1.9 days at $15.5^{\circ} \mathrm{C}$.

\subsection{Shelf life estimation}

The maximum stability times estimated at each temperature for each index $\left(\mathrm{CO}_{2}\right.$ production, TBA, e-nose $)$ and the method used for their definition are summarized in Table 3 . It is evident that the indices are in good agreement and can be used for the shelf life modeling.

When the temperature range of concern is relatively narrow $(0-$ $12^{\circ} \mathrm{C}$ ) then the shelf life of a product can be determined using the log shelf life model (Labuza \& Fu, 1993). In this case, the regression line between the parameter of concern, for example, end of shelf life (time needed for the appearance of visual defects or time needed by a chemical index or SSO to reach their maximum limit) and temperature is linear and described by the follow equation:

$t_{s}=t_{o} \exp (-b T)$

where $t_{s}$ is the stability time at temperature $T$; $t_{o}$ is the stability time (or shelf life) at $0{ }^{\circ} \mathrm{C}$ and $b$ is the slope of the regression line (Shi- moni \& Labuza, 2000). On the basis of these results, freshness of minced meat packaged in MAP is maintained for about 9 days at $4.3^{\circ} \mathrm{C}$ (recommended storage temperature), 3-4 days at $8.1^{\circ} \mathrm{C}$ (usual temperature in household refrigerators) and 2 days at $15.5^{\circ} \mathrm{C}$ (abuse temperature) (Table 3). The graphical resolution of Eq. (4) allows also the calculation of the $Q_{10}$, i.e. the increase in rate for a $10^{\circ} \mathrm{C}$ increase in temperature from the following equation:

$Q_{10}=\exp (10 b)$

where $b$ is the slope of each regression line (see Eq. (4)). The relevant $Q_{10}$ values are shown in Table 3, together with the mean values obtained from the different analyses. Again the values are in good agreement and can be usefully used to predict the shelf life of minced beef stored at different temperatures.

\section{Conclusions}

The data from the thermal histories during household storage showed that 3 times out 4 the temperature was equal to $8.4^{\circ} \mathrm{C}$, far from the optimal storage temperature for perishable foods.

From a microbiological point of view, LAB had higher rates of growth than Gram negative bacteria at the three temperatures probably due to the use of the high $\mathrm{CO}_{2}$ concentration (30\%) that allowed the growth of LAB, thus outcompeting other aerobic microorganisms. Moreover the higher activation energies of LAB indicated that their growth was affected more by temperature shifts than the growth of Gram negative microorganisms, with lower activation energies under the same conditions.

Shelf life studies require a fast and pragmatic approach: when safety is assured, some traits of the food quality can be monitored and conveniently modeled to give a limit value over which the product is not edible. The modeling of the experimental data and comparison with microbiological or chemical thresholds allowed the setting, for each index, of a stability time after which the meat was not acceptable.

The modeling of the development of $\mathrm{CO}_{2}$ inside the packages and its correlation with the microbial growth curves gave a limit value for $\mathrm{LAB}$ and Gram negative around $10^{7} \mathrm{ufc} / \mathrm{g}$, in accordance with other studies. The quality decay of minced meat was also successfully evaluated by means of a commercial e-nose, showing the potential of this instrument for the meat industry. A clear discrimination between "fresh" and "old" samples was obtained by PCA and CA, determining at each temperature a specific range of stability time. The mean value of the stability times calculated for each index was 9 days at $4.3^{\circ} \mathrm{C}$ (recommended storage temperature), 34 days at $8.1^{\circ} \mathrm{C}$ (usual temperature in household refrigerators) and 2 days at $15.5^{\circ} \mathrm{C}$ (abuse temperature). The graphical resolution of the stability times yielded $Q_{10}$ mean values, i.e. the increase in rate for a $10^{\circ} \mathrm{C}$ increase in temperature and thus a parameter useful to predict the shelf life of meat at different temperatures of storage. The results show that the $Q_{10}$ values from the traditional methods (3.6-4.0 range) overlapped with the $Q_{10}$ estimated with e-nose and color indexes (3.4 and 3.9, respectively). The electronic nose 
contributes to the description of the complex aroma profile that develops with the freshness decay of minced meat.

In conclusion, the shelf life study, based on selected and accelerated conditions of minced beef spoilage, yielded a time-temperature relationship useful to measure quality decay during some stages of meat marketing.

\section{Acknowledgement}

This work is dedicated to the memory of Professor Marco Riva, a valued colleague and scientist.

\section{References}

Akarpat, A., Turhan, S., \& Ustun, N. S. (2008). Effects of hot-water extracts from myrtle, rosemary, nettle and lemon balm leaves on lipid oxidation and color of beef patties during frozen storage. Journal of Food processing and Preservation, $32,117-132$.

Benedetti, S., Sinelli, N., Buratti, S., \& Riva, M. (2005). Shelf life of Crescenza cheese as measured by electronic nose. Journal of Dairy Science, 88, 3044-3051.

Blixt, Y., \& Borch, E. (1999). Using an electronic nose for determining the spoilage of vacuum-packaged beef. International Journal of Food Microbiology, 46, 123-134.

Boothe, D. D. H., \& Arnold, J. W. (2002). Electronic nose analysis of volatile compounds from poultry meat samples, fresh and after refrigerated storage. Journal of the Science of Food and Agriculture, 82, 315-322.

Brooks, J. C., Alvarado, M., Stephens, T. P., Kellermeier, J. D., Tittor, A. W., Miller, M. F., et al. (2008). Spoilage and safety characteristics of ground beef packaged in traditional and modified atmosphere packages. Journal of Food Protection, 71(2), 293-301.

Byun, J. S., Min, J. S., Kim, I. S., Kim, J. W., Chung, M. S., \& Lee, M. (2003). Comparison of indicators of microbial quality of meat during aerobic cold storage. Journal of Food Protection, 66(9), 1733-1737.

De Man, J. C., Rogosa, M., \& Sharpe, M. E. (1960). A medium for the cultivation of Lactobacilli. Journal of Applied Bacteriology, 23, 130-136.

Duong, D. Q., Crandalla, P. G., Pohlmanb, F. W., O'Bryana, C. A., Balentinea, C. W., \& Castilloc, A. (2008). Improving ground beef safety and stabilizing color during irradiation using antioxidants, reductants or TSP. Meat Science, 78(4), 359-368.

Ercolini, D., Russo, F., Torrieri, E., Masi, P., \& Villani, F. (2006). Changes in the spoilage-related microbiota of beef during refrigerated storage under different packaging conditions. Applied and Environmental Microbiology, 72(7), 4663-4671.

Friedrich, L., Siró, I., Dalmadi, I., Horváth, K., Ágoston, R., \& Balla, Cs. (2008). Influence of various preservatives on the quality of minced beef under modified atmosphere at chilled storage. Meat Science, 79, 332-343.

Gardner, J. W., \& Bartlett, P. N. (1994). A brief history of electronic noses. Sensors and Actuators B, 18, 211-220.

Georgantelis, D., Blekas, G., Katikou, P., Ambrosiadis, I., \& Fletouris, D. J. (2007). Effect of rosemary extract, chitosan and $\alpha$-tocopherol on lipid oxidation and color stability during frozen storage of beef burgers. Meat Science, 75, 256-264.

Giannuzzi, L., Pinotti, A., \& Zaritzky, N. (1998). Mathematical modelling of microbial growth in packaged refrigerated beef stored at different temperatures. International Journal of Food Microbiology, 39, 101-110.

Gray, J. I., Gomaa, E. A., \& Buckley, D. J. (1996). Oxidative quality and shelf life of meats. Meat Science, 43, S111-S123.

Hansen, T., Petersen, M. A., \& Byrne, D. V. (2005). Sensory based quality control utilising an electronic nose and GC-MS analyses to predict end-product quality from raw materials. Meat Science, 69, 621-634.

ISO-International Organization for Standardization (2003). ISO 4833 microbiology of food and animal feeding stuffs: Horizontal method for the enumeration of microorganisms colony-count technique at $30^{\circ} \mathrm{C}$

Jay, J. M. (1996). Microorganisms in fresh ground meats: The relative safety of products with low versus high numbers. Meat Science, 43, S59-S66.

Jayasingh, P., Cornforth, D. P., Brennand, C. P., Carpenter, C. E., \& Whittier, D. R. (2002). Sensory evaluation of ground beef stored in high-oxygen modified atmosphere packaging. Journal of Food Science, 67(9), 3493-3496.

Jul, M. (1984). Actual shelf life calculations. In M. Jul, The quality of frozen foods (pp. 209-221). London: Academic Press.

Kennedy, J., Jackson, V., Blair, I. S., McDowell, D. A., Cowan, C., \& Bolton, D. J. (2005). Food safety knowledge of consumers and the microbiological and temperature status of their refrigerators. Journal of Food Protection, 68, 1421-1430.

Kent, M., Oehlenschlager, J., Mierke-Klemeyer, S., Manthey-Karl, M., Knochel, R., Daschner, F., \& Schimmer, O. (2004). A new multivariate approach to the problem of fish quality estimation. Food Chemistry, 87, 531-535.
Khol, D. (1991). Fundamentals and recent developments of homogenous semiconducting sensors. In J. W. Gardner \& P. N. Bartlett (Eds.), Sensors and sensory systems for an electronic nose (pp. 53-76). Boston: Kluwer Academic Publishers.

Koutsoumanis, K., \& Nichas, G.-J. E. (2000). Application of a systematic experimenta procedure to develop a microbial model for rapid fish shelf-life prediction. International Journal of Food Microbiology, 60, 171-184.

Koutsoumanis, K. A., Stamatiou, A. P., Skandamis, P., \& Nychas, G.-J. E. (2006) Development of a microbial model for the combined effect of temperature and $\mathrm{pH}$ on spoilage of ground meat, and validation of the model under dynamic temperature conditions. Applied and Environmental Microbiology, 72(1), 124-134.

Koutsoumanis, K. P., Stamatiou, A. P., Drosinos, E. H., \& Nychas, G.-J. E. (2008). Control of spoilage microorganisms in minced pork by a self-developed modified atmosphere induced by the respiratory activity of meat microflora. Food Microbiology, 25, 915-921.

Labuza, T. P., \& Fu, B. (1993). Growth kinetics for shelf-life prediction: Theory and practice. Journal of Industrial Microbiology, 12, 309-323.

Lambert, A. D., Smith, J. P., \& Dodds, K. L. (1991). Shelf life extension and microbiological safety of fresh meat - A review. Food Microbiology, 8, 267-297.

Leak, F. W., \& Rönnow, P. (1999). Quality changes in ground beef during distribution and storage, and determination of time-temperature indicator (TTI) characteristics of ground beef. (May 8th 2009). <http://www.checkit.se/VitsabGBStudy1.pdf>.

Mancini, R. A., \& Hunt, M. C. (2005). Current research in meat colour. Meat Science, 71(1), 100-121.

Mataragas, M., Drosinos, E. H., Vaidanis, A., \& Metaxopoulos, I. (2006). Development of a predictive model for spoilage of cooked cured meat products and its validation under constant and dynamic temperature storage conditions. Journal of Food Science, 71(6), M157-M167.

McMeekin, T. A., \& Ross, T. (1996). Shelf life prediction: Status and future possibilities. International Journal of Food Microbiology, 33, 65-83.

McMillin, K. W. (2008). Where is MAP going? A review and future potential of modified atmosphere packaging for meat. Meat Science, 80(1), 43-65.

Nassos, P. S., King, A. D., Jr., \& Stafford, A. E. (1983). Relationship between lactic acid concentration and bacterial spoilage in ground beef. Applied Environmental Microbiology, 46, 894-900.

O'Grady, M. N., Monahan, F. J., Burke, R. M., \& Allen, P. (2000). The effect of oxygen level and exogenous $\alpha$-tocopherol on the oxidative stability of minced beef in modified atmosphere packs. Meat Science, 55, 39-45.

Olsen, E., Vogt, G., Ekeberg, D., Sandbakk, M., Pettersen, J., \& Nilsson, A. (2005). Analysis of the early stages of lipid oxidation in freeze-stored pork back fat and mechanically recovered poultry meat. Journal of Agriculture and Food Chemistry, $53,338-348$.

Raharjo, S., Sofos, J. N., \& Schmidt, G. R. (1993). Solid-phase acid extraction improves thiobarbituric acid method to determine lipid oxidation. Journal of Food Science, 4, 921-924.

Rajamäki, T., Alakomi, H. L., Ritvanen, T., Skyttä, E., Smolander, M., \& Ahvenainen, R (2006). Application of an electronic nose for quality assessment of modified atmosphere packaged poultry meat. Food Control, 17, 5-13.

Ruiz de Huidobro, F., Miguel, E., Onega, E., \& Blázquez, B. (2003). Changes in meat quality characteristics of bovine meat during the first 6 days postmortem. Meat Science, 65(4), 1439-1446.

Shahidi, F., Yun, J., Rubin, L. J., \& Wood, D. F. (1987). The hexanal content as an indicator of oxidative stability and flavor acceptability in cooked ground pork. Canadian Institute of Food Science and Technology Journal, 20, 104-106.

Shimoni, E., \& Labuza, T. P. (2000). Modeling pathogen growth in meat products: Future challenges. Trends in Food Science \& Technology, 11, 394-402.

Sierra, V., Aldai, N., Castro, P., Osoro, K., Coto-Montes, A., \& Oliván, N. (2008) Prediction of the fatty acid composition of beef by near infrared transmittance spectroscopy. Meat Science, 78(3), 248-255.

Sinelli, N., Barzaghi, S., Giardina, C., \& Cattaneo, T. M. P. (2005). Use of the FT-NIR spectroscopy to monitor the shelf-life of packed industrial Ricotta cheese. Journal of Near Infrared Spectroscopy, 13, 293-300.

Tarladgis, B. G., Watts, B. M., Younathan, M. T., \& Dugan, L. R. (1960). A distillation method for the quantitative determination of malonaldehyde in rancid foods. Journal of American Oil Chemistry Society, 37, 44-48.

Vestergaard, J. S., Martens, M., \& Turkki, P. (2007). Analysis of sensory quality changes during storage of a modified atmosphere packaged meat product (pizza topping) by an electronic nose system. Food Science and Technology, 40, 1083-1094.

Winquist, F., Hörnsten, E. G., Sundgren, H., \& Lundström, I. (1993). Performance of an electronic nose for quality estimation of ground meat. Measurement Science and Technology, 4, 1493-1500.

Zhu, M. J., Mendonca, A., \& Ahn, D. U. (2004). Temperature abuse affects the quality of irradiated pork loins. Meat Science, 67, 643-649.

Zwietering, M. H., De Koos, J. T., Hasenack, B. E. J. C., De Witt, J. C., \& Van’t Riet, K. (1991). Modeling of bacterial growth as a function of temperature. Applied and Environmental Microbiology, 57, 1094-1101. 